\title{
PENGARUH PENDAPATAN ASLI DAERAH (PAD) DAN BELANJA MODAL TERHADAP KEMANDIRIAN KEUANGAN DAERAH
}

\author{
Eve Ida Malau ${ }^{1}$ Eka Pratiwi Septania Parapat ${ }^{2}$ \\ ${ }^{1}$ Akuntansi, Sekolah Tinggi Akuntansi dan Manajemen Indonesia \\ email: eveidamalau@gmail.com \\ ${ }^{2}$ Akuntansi, Sekolah Tinggi Akuntansi dan Manajemen Indonesia \\ email: ekapsparapat@gmail.com
}

\begin{abstract}
The objective of the research was to analized the influence original local revenue and capital expenditure partially on the independence of local finance in districts/towns of North Sumatera Province. The population was 33 districts/towns of North Sumatera Province years of 2010-2017 and population will be used as sample. The data were processed by using panel data regression statistic method. The result of the research that original local revenue had positive and significant influence on the independence of local finance. Meanwhile, capital expenditure had negative and significant influence on the independence of local finance.
\end{abstract}

Keywords : Original Local Revenue, Capital Expenditure, Independence of Local Finance.

\section{PENDAHULUAN}

Realisasi pengelolaan keuangan daerah menjadi salah satu bentuk penerapan otonomi daerah yang ditujukan untuk memperbaiki kesejahteraan masyarakat di Indonesia. Pernyataan ini sesuai dengan instruksi undangundang No. 32 tahun 2004 mengenai Pemerintahan Daerah yang memberikan peluang bagi daerah untuk mewujudkan keuangan daerah yang mandiri [1][2].

Daerah yang mandiri adalah apabila pendapatan asli daerah sebagai sumber penerimaan yang utama dalam membiayai pengeluaran daerah sehingga tidak bergantung pada pinjaman kepada stakeholder, pemerintah provinsi maupun pusat. Kemandirian daerah ditujukan untuk menggambarkan rasio ketergantungan pada sumber pendanaan pihak eksternal [3]. PAD menjadi sumber pendapatan yang harus dieksplor daerah berdasarkan peraturan yang berlaku. Penelitian yang dilakukan di kota Tasikmalaya, menunjukkan PAD memiliki pengaruh yang signifikan terhadap kemandirian keuangan [4]. Hal ini dicapai pemerintah daerah melalui peningkatan kinerja dan perluasan sumber pendapatan lain- lain yang sah, yaitu hasil penjualan aset lainnya dan pendapatan jasa layanan umum.

Pemerintah daerah memiliki ketergantungan yang tinggi terhadap transfer pemerintah pusat dalam menjalankan berbagai program dan kegiatan pembangunannya [5]. Hal ini mengindikasikan adanya kelemahan dalam PAD yang masih belum dapat ditingkatkan untuk menutupi belanja daerah terutama belanja modal yang merupakan pengeluaran terbesar jika dibandingkan dengan belanja pegawai dan belanja barang. Sehingga untuk menutupi tingginya belanja daerah, pemerintah daerah masih harus bergantung pada alokasi dana perimbangan dari pemerintah pusat. Terdapat penelitian yang menyatakan bahwa belanja modal berpengaruh dan signifikan negatif terhadap kemandirian keuangan daerah [6]. Selain itu terdapat juga penelitian yang menyatakan belanja modal tidak memiliki pengaruh signifikan terhadap kemandirian daerah [7]. Hal ini karena belanja modal yang dilakukan pemerintah daerah lebih banyak digunakan untuk belanja pelayanan dasar seperti membangun gedung kantor dan pembelian peralatan perkantoran dibandingkan dengan 
membangun infrastruktur seperti jalan dan jembatan.

Berdasarkan hasil kajian tersebut maka penelitian ini sangat menarik untuk dikaji kembali sehingga dapat memberikan manfaat yang baik kepada masyarakat dan pemangku kepentingan pemerintah daerah khususnya dalam mengelola semua potensi sumber penerimaan daerah yang ada. Penelitian ini dilakukan di Provinsi Sumatera Utara dengan 33 kabupaten/kota yang diharapkan dapat memberikan gambaran mengenai kemandirian keuangan daerah di kabupaten/kota Provinsi Sumatera Utara. Peneliti akan menguji PAD dan belanja modal dalam mempengaruhi kemandirian keuangan daerah dengan lag 1 tahun.

\subsection{Signalling Theory}

Teori signalling dikembangkan sebagai upaya untuk memberikan sinyal informasi dari pihak yang lebih memiliki informasi kepada pihak stakeholder yang kurang memiliki informasi di perusahaan [8]. Teori signalling pada sektor publik ditujukan pada upaya pemerintah memberikan sinyal dalam bentuk informasi keuangan yang berkualitas yang implementasinya dirasakan oleh masyarakat dari pelayanan publik yang telah disediakan pemerintah. Kemandirian keuangan daerah perlu untuk diinformasikan kepada masyarakat sebagai bentuk kemampuan daerah dalam mengelola ketersediaan sumber daya daerah. Keterkaitan teori signalling terhadap penelitian ini adalah menjelaskan pemerintah daerah sebagai pihak yang menjalankan roda pemerintahan memberikan sinyal informasi keuangan daerah yang secara optimal dilaksanakan untuk kesejateraan masyarakat.

\subsection{Kemandirian Keuangan Daerah}

Kemandirian keuangan daerah adalah kemampuan daerah untuk menggali potensi sumber daya sehingga dapat mengurangi atau tidak bergantung pada pihak eksternal daerah. Keuangan daerah yang mandiri menunjukkan kemampuan pemerintah dalam membiayai operasional pemerintahan dan pembangunan daerah dengan menggunakan sumber pendapatan asli daerah [9]. Kemandirian keuangan daerah dapat ditunjukkan dari perbandingan besarnya nilai PAD terhadap penerimaan transfer dari pusat maupun pinjaman daerah.

\subsection{Pendapatan Asli Daerah (PAD)}

Pendapatan asli daerah adalah instrumen yang digunakan untuk menilai kemandirian keuangan daerah. PAD dihasilkan daerah dari pemanfaatan sumber daya daerah yang mencakup pajak, retribusi, hasil pengelolaan kekayaan daerah yang dipisahkan, dan pendapatan sah lainnya [10]. Kemandirian keuangan daerah diharapkan dapat dicapai oleh setiap daerah melalui peningkatan PAD sehingga tidak bergantung pada penerimaan dari pihak eksternal sebagai penerimaan utama.

Beberapa penelitian menyatakan bahwa PAD berpengaruh positif signifikan terhadap kemandirian keuangan daerah [3][11][12][13]. Berdasarkan penelitian tersebut maka hipotesisnya adalah:

H1 : Pendapatan asli daerah berpengaruh positif terhadap kemandirian keuangan daerah

\subsection{Belanja Modal}

Belanja modal merupakan salah satu sarana yang dimiliki oleh pemerintah daerah dalam menunjang pelayanan publik [14]. Pembangunan infrastruktur dan sarana pelayanan publik merupakan bentuk dari belanja modal yang diharapkan dapat meningkatkan kemandirian daerah di masa yang akan datang. Sehubungan dengan itu, maka belanja modal diharapkan dapat ditingkatkan melalui produktivitas daerah sehingga dapat mandiri dari aspek keuangan.

Penelitian membuktikan bahwa belanja modal memiliki pengaruh signifikan negatif terhadap kemandirian keuangan daerah [6]. Terdapat juga penelitian yang menyatakan bahwa belanja modal memiliki koefisien positif tetapi tidak signifikan berpengaruh terhadap kemandirian daerah [7]. Berdasarkan penelitian tersebut maka hipotesisnya adalah:

$\mathrm{H} 2$ : Belanja modal berpengaruh negatif terhadap kemandirian keuangan daerah

\section{METODE PENELITIAN}

\subsection{Objek dan Sampel Penelitian}

Penelitan ini dilakukan di kabupaten/kota Provinsi Sumatera Utara, dimana populasi digunakan sebagai sampel penelitian yang terdiri 
DOI 10.37600/ekbi.v3i2.196

dari 33 kabupaten/kota tahun 2010 s.d 2017 yaitu berjumlah 264 sampel. Data penelitian bersumber dari situs Direktorat Jenderal Perimbangan Keuangan Pusat dan Daerah (http://www.djpk.depkeu.go.id).

\subsection{Definisi Operasional Variabel}

Pendapatan asli daerah adalah penerimaan daerah pada tahun anggaran yang diperoleh dari pemanfaatan sumber daya daerah. PAD diukur berdasarkan realisasi pendapatan asli daerah kabupaten/kota Provinsi Sumatera Utara tahun 2010-2017.

Belanja modal adalah pengeluaran yang memiliki manfaat jangka panjang pada tahun anggaran yang dapat dimanfaatkan sebagai sumber penerimaan daerah. Belanja Modal diukur berdasarkan realisasi belanja modal Kabupaten/Kota Provinsi Sumatera Utara tahun 2010-2017.

Kemandirian keuangan daerah adalah kemampuan daerah untuk mengelola keuangan daerah tanpa harus bergantung dengan pendanaan pihak eksternal. Kemandirian keuangan daerah diukur dengan rasio kemandirian berdasarkan realisasi PAD dan realisasi bantuan pemerintah pusat/provinsi serta pinjaman Kabupaten/Kota Provinsi Sumatera Utara tahun 2011-2018 [6], yaitu:

$\frac{\text { PAD }}{\text { Bantuan Pemerintah Pusat/Provingi dan Pinjaman }} \times 100 \%$

\subsection{Teknik Analisis Data}

Penelitian ini menggunakan analisis regresi data panel dengan Eviews 10, dimana persamaan regresi linear berganda dalam penelitian ini yaitu:

$\mathrm{Y}_{\mathrm{t}}=\alpha+\beta 1 \mathrm{X} 1_{\mathrm{t}-1}+\beta 2 \mathrm{X} 2_{\mathrm{t}-1}+\mathrm{e}_{\mathrm{t}-1}$

Dimana:

$$
\begin{array}{ll}
\mathrm{t} & : \text { Tahun } \\
\mathrm{Y} & : \text { Kemandirian Keuangan Daerah } \\
\alpha & : \text { Konstanta } \\
\beta_{1-2} & : \text { Koefisien Regresi } \\
\mathrm{X} 1 & : \text { Pendapatan Asli Daerah } \\
\mathrm{X} 2 & : \text { Belanja Modal } \\
\mathrm{e} & \text { : Error }
\end{array}
$$

\section{HASIL DAN PEMBAHASAN}

\subsection{Analisis Statistik Deskriptif}

Analisis ini digunakan untuk mengetahui gambaran suatu data yang ditinjau dari nilai minimum, nilai maksimum, nilai ratarata (mean), dan nilai standar deviasi. Dalam penelitian ini, variabel yang digunakan dalam perhitungan statistik deskriptif adalah nilai kemandirian keuangan daerah (KKD), pendapatan asli daerah (PAD) dan belanja modal (BM). Gambaran statistik deskriptif disajikan sebagai berikut.

Tabel 3.1. Statistik Deskriptif Berdasarkan Variabel KKD, PAD dan BM

\begin{tabular}{cccc}
\hline Variable & KKD & PAD & BM \\
\hline Minimum & 0.0106 & 1057429832.00 & 16833467955.00 \\
Maximum & 1.3828 & 1739756922634.00 & 997475991902.00 \\
Mean & 0.1105 & 99140662160.18 & 200837273545.63 \\
$\begin{array}{c}\text { Std. } \\
\text { Deviation }\end{array}$ & 0.1646 & 236984825944.56 & 138747457914.73 \\
\hline
\end{tabular}

Sumber: Hasil Olah Software Eviews 10

Berdasarkan Tabel 3.1, diketahui nilai minimum dari KKD adalah 0,0106, sementara nilai maksimum dari KKD adalah 1,3828. Ratarata KKD adalah 0,1105, dengan standar deviasi 0,1646 . Diketahui nilai minimum dari PAD adalah 1057429832, sementara nilai maksimum dari PAD adalah 1739756922634. Rata-rata PAD adalah 99140662160.18, dengan standar deviasi 236984825944.56. Diketahui nilai minimum dari BM adalah 16833467955, sementara nilai maksimum dari BM adalah 997475991902. Rata-rata BM adalah 200837273545.63, dengan standar deviasi 138747457914.73 .

3.2. Menentukan Model Estimasi antara Fixed Effect Model (FEM) dan Random Effect Model (REM) dengan Uji Hausman

Dalam menentukan apakah model estimasi FEM atau REM yang membentuk model regresi, maka dilakukan uji Hausman. Berikut hasil berdasarkan uji Hausman dengan menggunakan Eviews 10.

Tabel 3.2 Hasil dari Uji Hausman 
DOI 10.37600/ekbi.v3i2.196

\begin{tabular}{lrrr} 
Test Summary & $\begin{array}{c}\text { Chi-Sq. } \\
\text { Statistic }\end{array}$ & Chi-Sq. d.f. & Prob. \\
\hline \hline Cross-section random & 13.229919 & 2 & 0.0013 \\
\hline
\end{tabular}

Sumber: Hasil Olah Software Eviews 10

Berdasarkan Tabel 3.2, diketahui nilai probabilitas adalah 0,0013. Karena nilai probabilitas $0,0013<0,05$, maka model fixed effect model (FEM) digunakan sebagai model estimasi.

\subsection{Pengujian Hipotesis}

Pada pengujian hipotesis, akan dilakukan analisis koefisien determinasi, pengujian pengaruh simultan (uji F), dan pengujian pengaruh parsial (uji t). Nilai statistik dari koefisien determinasi, uji $\mathrm{F}$, dan uji $\mathrm{t}$ tersaji pada Tabel 3.3.

Tabel 3.3 Nilai statistik dari Koefisien Determinasi,Uji F, dan Uji t

\begin{tabular}{lrlrr}
\hline \hline \multicolumn{1}{c}{ Variable } & Coefficient & Std. Error & t-Statistic & Prob. \\
\hline \hline \multicolumn{1}{c}{ X1? } & 0.132428 & 0.012595 & 10.51445 & 0.0000 \\
$\quad$ X2? & -0.103115 & 0.019022 & -5.420716 & 0.0000 \\
\multicolumn{1}{c}{ C } & -0.459583 & 0.321112 & -1.431221 & 0.1537 \\
\hline \hline $\begin{array}{l}\text { R-squared } \\
\text { Adjusted R- }\end{array}$ & $\mathbf{0 . 7 8 7 6 1 7}$ & Mean dependent var & 0.110514 \\
squared & 0.756085 & S.D. dependent var & 0.164556 \\
$\begin{array}{l}\text { S.E. of } \\
\text { regression }\end{array}$ & 0.081271 & Akaike info criterion & -2.059138 \\
$\begin{array}{l}\text { Sum squared } \\
\text { resid }\end{array}$ & 1.512527 & Schwarz criterion & -1.585054 \\
$\begin{array}{l}\text { Log likelihood } \\
\text { F-statistic }\end{array}$ & 306.8063 & Hannan-Quinn criter. & -1.868637 \\
$\begin{array}{l}\text { Prob(F- } \\
\text { statistic) }\end{array}$ & 24.97774 & Durbin-Watson stat & 1.984790 \\
\hline
\end{tabular}

Sumber: Hasil Olah Software Eviews 10

\subsection{Analisis Koefisien Determinasi}

Berdasarkan Tabel 3.3, nilai koefisien determinasi ( $R$-squared) sebesar $R^{2}=0,7876$. Nilai tersebut dapat diartikan PAD, belanja modal secara simultan mempengaruhi kemandirian keuangan daerah sebesar $78,76 \%$, sisanya sebesar $21,24 \%$ dipengaruhi oleh faktor lainnya.

\subsection{Uji Signifikansi Pengaruh Simultan (Uji F) \\ Uji $F$ bertujuan untuk menguji adanya} pengaruh variabel bebas secara simultan terhadap variabel tak bebas. Berdasarkan Tabel 4.3, diketahui nilai Prob. (F-statistics), yakni $0,00000<0,05$, dapat disimpulkan bahwa variabel bebas, yakni PAD dan belanja modal memiliki pengaruh yang signifikan terhadap kemandirian keuangan daerah.

\subsection{Persamaan Regresi Data Panel dan Uji} Signifikansi Pengaruh Parsial (Uji t)

Berdasarkan Tabel 3.3, diperoleh persamaan regresi linear berganda sebagai berikut.

$\mathrm{Y}=-0,45+0,13 \mathrm{X} 1-0,10 \mathrm{X} 2+\mathrm{e}$

Berdasarkan Tabel 3.3, diketahui:

1. PAD berpengaruh positif terhadap kemandirian keuangan daerah, dengan nilai koefisien regresi 0,13 dan signifikan dengan nilai Prob. $0,0000<0,05$. Sehingga PAD berpengaruh positif signifikan terhadap kemandirian keuangan daerah.

2. Belanja modal berpengaruh negatif terhadap kemandirian keuangan daerah, dengan nilai koefisien regresi $-0,10$ dan signifikan dengan nilai Prob. 0,0000 < 0,05. Sehingga belanja modal berpengaruh negatif signifikan terhadap kemandirian keuangan daerah.

\subsection{PEMBAHASAN}

\subsubsection{PAD Terhadap Kemandirian Keuangan Daerah}

PAD adalah pendapatan yang bersumber dari setiap orang atau badan yang menggunakan jasa atau fasilitas dari pemerintah daerah berdasarkan peraturan yang berlaku. Hasil pengujian penelitian ini adalah PAD berpengaruh positif terhadap kemandirian keuangan daerah, artinya bahwa setiap kenaikan PAD akan diikuti dengan peningkatan kemandirian keuangan daerah. Hal ini menunjukkan hipotesis pertama penelitian ini diterima. Penelitian ini sesuai dengan teori signalling dimana pemerintah daerah memberi sinyal informasi kenaikan pendapatan asli daerah sebagai capaian kemandirian keuangan daerah. Pemerintah daerah mampu menggali potensi sumber daya daerah sehingga tidak terlalu bergantung pada pemerintah provinsi/pusat

\subsubsection{Belanja Modal Terhadap Kemandirian Keuangan Daerah \\ Belanja modal merupakan pengeluaran}


yang dialokasikan untuk meningkatkan aset daerah yang berpotensi sebagai sumber pendapatan daerah. Hasil pengujian dalam penelitian ini membuktikan belanja modal berpengaruh negatif terhadap kemandirian keuangan daerah, artinya kenaikan belanja modal menyebabkan penurunan kemandirian keuangan daerah. Hal ini menunjukkan hipotesis kedua dalam penelitian ini diterima. Penelitian ini sesuai dengan teori signalling bahwa pemerintah daerah memberikan informasi kenaikan belanja modal yang digunakan untuk pembangunan fasilitas publik. Kenaikan belanja modal sebagai bukti bahwa pemerintah daerah mengutamakan kepentingan umum dengan membangun fasilitas publik walaupun dalam hal ini dapat menyebabkan kemandirian keuangan daerah menurun.

\section{KESIMPULAN}

Dari penelitian diatas, maka dapat disimpulkan, PAD berpengaruh positif terhadap kemandirian keuangan daerah. Sebaliknya belanja modal berpengaruh negatif terhadap kemandirian keuangan daerah. Saran yang disampaikan adalah agar bagi penelitian berikutnya dapat menambah variabel lain yang dapat mempengaruhi kemandirian keuangan daerah serta memperpanjang perbedaan waktu (lag) dari penelitian.

\section{REFERENSI}

[1] K. R. Ariani and G. A. Putri, "Pengaruh Belanja Modal Dan Dana Alokasi Umum Terhadap Tingkat Kemandirian Keuangan Daerah," Semin. Nas. dan 3rd Call Syariah Pap., pp. 364-369, 2016.

[2] T. U. Handayani and Erinos, "Pengaruh Pendapatan Asli Daerah Dan Belanja Modal Terhadap Tingkat Kemandirian Keuangan Daerah Dengan Pertumbuhan Ekonomi Sebagai Variabel Moderating," J. Eksplor. Akunt., vol. 2, no. 1, pp. 23482361, 2020.

[3] K. P. Sanga, S. B. Hermanto, and N. Handayani, "Pengaruh Penerimaan Daerah
Terhadap Kemandirian Keuangan Daerah Dengan Belanja Modal Sebagai Variabel Intervening," Konf. Reg. Akunt. V Malang, pp. 1-28, 2018.

[4] R. N. R. Andriani and N. N. Wahid, "Pengaruh Pendapatan Asli Daerah Dan Dana Perimbangan Terhadap Kemandirian Keuangan Daerah," J. Akunt., vol. 13, no. 1, pp. 30-39, 2018.

[5] N. T. Erawati and L. Suzan, "Pengaruh Pendapatan Asli Daerah Terhadap Tingkat Kemandirian Keuangan Daerah Kota Bandung," e-Proceeding Manag., vol. 2, no. 3, pp. 3259-3266, 2015.

[6] E. T. R. Darwis, "Pengaruh Belanja Modal dan Belanja Pegawai Terhadap Tingkat Kemandirian Keuangan Daerah Pada Kabupaten/Kota Provinsi Sumatera Barat," pp. 1-23, 2015.

[7] N. Andriana, "Pengaruh Dana Perimbangan Dan Belanja Modal Terhadap Kemandirian Daerah," J. Pajak dan Keuang. Negara, vol. 2, no. 1, pp. 105-113, 2020.

[8] T. Gumanti, "Teori Sinyal Dalam Manajemen Keuangan," Researchgate, pp. 1-29, 2009.

[9] C. D. Sumual and N. G. , Lintje Kalangi., "Analisis Pengukuran Kinerja Keuangan Pada Pemerintah Kota Tomohon," J. Ris. Akunt. Going Concern, vol. 12, no. 2, pp. 782-791, 2017.

[10] R. Saleh, "Pengaruh Pendapatan Asli Daerah (PAD) Dan Dana Perimbangan Terhadap Kemandirian Keuangan Pemerintah Daerah," J. Informasi, Perpajakan, Akuntansi, dan Keuang. Publik, vol. 15, no. 2, pp. 111-134, 2020.

[11] A. Lestari, N. Dali, and M. Abdullah, "Pengaruh Dana Alokasi Umum (Dau) Dan Pendapatan Asli Daerah (Pad) Terhadap Belanja Modal Dan 
Kemandirian Keuangan Daerah Provinsi Sulawesi Tenggara," J. Prog. Ekon. Pembang., vol. 1, no. 2, pp. 44-55, 2016.

[12] L. Yuliyanti, N. Nugraha, and Y. K. Fadilah, "The Influence of Local OwnSource Revenue towards Regional Financial Independence," vol. 65, no. Icebef 2018, pp. 4-7, 2019.

[13] M. Tahar, Afrizal dan Zakhiya, "Pengaruh Pendapatan Asli Daerah Dan Dana Alokasi Umum Terhadap Kemandirian
Daerah Dan Pertumbuhan Ekonomi Daerah," J. Akutansi dan Investasi, vol. 12, no. 1, pp. 88-99, 2011.

[14] H. Afifah Fauziah Amalia N, "Analisis Pengaruh Pendapatan Asli Daerah, Dana Alokasi Umum, Dan Belanja Modal Terhadap Tingkat Kemandirian Keuangan Daerah Pada Pemerintah Daerah Kabupaten/Kota Di Provinsi Jawa Tengah Tahun 2012-2017," Diponegoro J. Account., vol. 8, no. 2, pp. 1-13, 2019. 